\title{
The Innovation of "Ideological and Political Class" Practice Teaching in Higher Vocational Colleges
}

\author{
San-Chi SHE \\ Institute of Marxism, Wuhan polytechnic, Wuhan 430074, China \\ 86875744@qq.com \\ ${ }^{*}$ Corresponding author
}

Keywords: The ideological and political class, The practice teaching, Higher vocational colleges, innovation.

\begin{abstract}
This paper describes the innovation of the practice teaching of "ideological and political class " in higher vocational colleges. This paper mainly includes the significance, thought and countermeasure of the practice teaching of thought and political lesson. Finally, the paper also describes the safeguard mechanism of the practical teaching of the thought courses.
\end{abstract}

\section{It is of Great Significance to Strengthen the Practical Teaching of Ideological and Political Courses in Higher Vocational Colleges}

Firstly, the practical teaching of ideological and political class embodies Marxist theory of practice. It is the essential demand of Marxist theory, the combination of theory and practice, which is the essential characteristic of Marxism and the basic principle of Marxism. To strengthen the thought political lesson teaching reform will be more effective in stimulating the enthusiasm of students to participate in the practice teaching and enthusiasm, make the student both brain and hand, learning is thought, think to think, gains enlightenment, so as to realize the unification of knowing and doing ".

Secondly, the practice teaching of ideological and political class is the requirement of the development of modern education theory. Modern education emphasizes that "based on students" education thought, schools in the education of knowledge at the same time, it should be education students to use the existing knowledge to solve practical problems, to explore the unknown in practice. In at the same time to improve the quality of theoretical teaching, therefore, must strengthen the practical teaching, arouse the enthusiasm of students to the thought political lesson and identity, stimulate student activeness in the thought political lesson study.

Thirdly, it is the need of social practice to strengthen the practical teaching of "ideological and political class". Comrade Xiao-ping DENG pointed out that education should be oriented towards modernization, facing the world and facing the future. "The thought political lesson" to do "three facing", you must adapt to the needs of socialist modernization construction in China, making school thought political lesson education in a completely open social environment, the students' concept of honor and disgrace, judgments and values more from society. The thought political lesson if higher vocational colleges is still with the traditional closed teaching mode, "heavy theory, light practice", "light weight class, extracurricular", ignore the contemporary students demand for people's autonomy and creativity, the thought political lesson on the teaching effect, will look weak.

\section{The Current Higher Vocational College Innovation "Thought Politics Lesson" Practice Teaching Thought}

\section{Focus on Constructing a New System of Practical Teaching}

What is social the practice teaching. This concept is the logical starting point of the practice teaching. The teaching of social practice is based on the social experience and the student's personal experience, in the application, observation and experience, the basic principles of the ideological 
and political theory course teaching; Its essence is to make use of social practice, make use and experience, finally make the study theory turns into the student's wisdom.

To clarify the orientation of social practice teaching in the whole teaching. According to the teaching characteristics of ideological theory, the teaching of course can be divided into theory teaching and practice teaching part to complete, according to the proportion of 2:1 is divided into theory teaching and practice teaching, in time, the extension of social practice teaching should be theory teaching, extension, and further, cooperate with theory teaching simultaneously.

To clarify the orientation of classroom teaching of social practice. The practice teaching of ideological and political theory should be "classfied". Practical teaching can neither be taught in the classroom, nor can it be seen in the form. Therefore, this "classroom" should "look", "listen" and "feel"; "Write" and "communicate".

\section{Innovative Practical Teaching Approach}

At present, the ideological theory class teaching mode of the practical teaching, emphasize the teachers lead as the center, the students passively participate in practice is given priority to, most simple visit, investigation and other methods, student participation is not high, the old teaching methods. Therefore, it is imperative to reform and explore the teaching methods of practical teaching.

Carry out the teaching of understanding practice. It mainly USES visiting, observation and video viewing, etc. It is to organize students to visit the practice base to study.

Practical experience teaching. This kind of teaching is divided into direct experience and indirect experience. The direct experience is to organize students to participate in local social practice. Take advantage of double day to practice teaching base obligation labor, "enter the community" activity, attend "three lower countryside" and so on. The indirect experience is to let students listen to social practice reports.

Practical problem research and teaching. This kind of teaching includes practical subject discussion and practical simulation. Practical topics are discussed by teachers to organize students to participate in teaching related research projects, discuss some difficult points and hotspot issues, and improve the ability to use theoretical knowledge to solve practical problems. Practice simulation, such as simulated moral conflict, simulated court, etc.

\section{Countermeasures of the Practice Teaching of "Ideological and Political Class" in Higher Vocational Colleges}

To establish a social practice leadership system in the ideological and political class. The effect of social practice of ideological and political class is an important factor influencing the teaching effect of ideological and political class. Many teachers and leaders in colleges and universities have little understanding of the importance of social practice of ideological and political class, which leads to lack of strong support and guarantee in terms of financial input and organizational leadership. Therefore, the leadership of the party committee should be established as the main body of the President and the administrative system. Leaders should take part in the theoretical teaching and social practice of ideological and political courses, understand the situation, solve problems, and guarantee the effective operation of the theory teaching and social practice teaching of "ideological and political class".

We will improve the social practice management system of ideological and political courses. On the basis of raising the ideological awareness, we should strengthen the leadership and management of the social practice of ideological and political class. Thought political lesson by "going out" is social practice method, and the thought political lesson teacher authority is limited, it is difficult to obtain social party in the face of the support of social practice, which requires the school organization management department to lead and coordinate. Should, therefore, the party secretary of the party and in charge of teaching direct leadership, authority, vice President of the clear and powerful management system of the command, unified organization and coordination of thought political lesson of the social practice activities, the thought political lesson social practice activities 
of the organization and leadership, achievement appraisal, reward method, computing workload and related policies and make clear a regulation, make its rules-based.

\section{Establish and Improve the Practice Teaching Safeguard Mechanism}

The effect of social practice of ideological and political class involves teachers' power, content, form, funds and places. Therefore, it is important to establish and improve the safeguard mechanism of the social practice of ideological and political courses while establishing and improving the leadership system.

Think seriously, change the idea. The effect of social practice of ideological and political class depends on the understanding of social practice of ideological and political class. Thought political lesson teacher to improve the understanding of social practice of the thought political lesson, establish the thought political lesson social practice is an important part of the education idea, change the thought political lesson the thought of social practice dispensable, take an active part in social practice of the thought political lesson study, practice and innovation. Let the student through the thought political lesson social practice, the organic combination of theory and practice, since the reform and opening to the outside party can be fully understand the correctness of the line, principles and policies formulated by the, enhance the consciousness of carrying out, at the same time, through the visit, with emphasis on the patriotic education, further carry forward and cultivate national spirit. Therefore, thought political lesson teacher must change the teaching mode, actively organize the student to carry out the thought political lesson social practice activities, make college students in the practice activity to form the correct world outlook, the outlook on life and values, so as to achieve the essence of the thought political lesson teaching function.

Select teachers and strengthen guidance. Thought political lesson social practice should be selected with love thought political lesson teaching, has the dedication to work and the sense of responsibility, love students, teachers as a guide, may also employ a number of school teachers, together with the school teachers specific guidance thought political lesson social practice activities, so as to ensure the effect of social practice. External guidance teachers participate in the discussion and revision of the school's social practice plan, as well as research and summary of social practice activities. In this way, we can guarantee the effect of social practice activities in the ideological and political class and achieve the purpose of activities.

\section{Summary}

Only fully realize the significance of the thought political lesson teaching innovation, straighten out the thinking of "the thought political lesson teaching innovation, the innovation" the thought political lesson teaching countermeasures, and establish the guarantee mechanism of "the thought political lesson teaching practice, can we truly achieve the thought political lesson teaching innovation.

\section{References}

[1] Shao-wu LIU. To find the characteristic way of teaching reform of ideological and political theory in higher vocational colleges[J]. Heilongjiang education(High education research and evaluation), 2007, (12): 63-65.

[2] Li-jun QIN,Zeng-an LIU. The teaching content of "ideological and political class" in higher vocational colleges is integrated[J]. Education and vocational. 2006, (20): 145-146.

[3] Gui-hua YU. Attempt to reform the teaching method of ideological and political teaching in higher vocational colleges[J]. University education research.2008, (6):65-66.

[4] Ya-yu WANG. Reform of ideological and political education in colleges and universities[J]. Learning issue.2016, 02. 